\begin{tabular}{c} 
Volume and Issues Obtainable at Center for Sustainability Research and Consultancy \\
Journal of Business and Social Review in Emerging Economies \\
ISSN: 2519-089X \& ISSN (E): 2519-0326 \\
Volume 7: Issue 2 June 2021 \\
CSRட \\
Journal homepage: www.publishing.globalcsrc.org/jbsee \\
\hline
\end{tabular}

\title{
The Effectiveness of Early Childhood Education Program in Public Schools of Punjab
}

Saima Malik, Higher Education Department, Punjab, Pakistan

*Muhammad Zaheer Asghar, Department of Education, University of Management and

Technology, Lahore, Pakistan and Fellow, Education \& ICT (e-learning), Universitat Oberta de

Catalunya, Barcelona

*Corresponding author's email: zaheer.asghar@umt.edu.pk

\begin{tabular}{l}
\hline ARTICLE DETAILS \\
\hline History \\
Revised format: April 2021 \\
Available Online: May \\
2021
\end{tabular}

Keywords

Early Childhood Education,

Quaid-e-Azam Academy for

Educational Development,

Physical Facilities,

retention rate in ECE,

enrollment rate in ECE

\section{JEL Classification}

IO,I2

\begin{abstract}
Purpose: The present study aimed to evaluate the effectiveness of the current Early Childhood Education (ECE) Program regarding the facilities provided in Public Schools of Punjab. The study was quantitative in nature.
\end{abstract}

Design/Methodology/Approach: The study was quantitative in nature. Eleven districts out of fourteen districts of central Punjab were selected randomly. A self-developed checklist was deployed to collect data from public ECE schools of Punjab through a convenient sampling technique. The reliability of the checklist was measured through the pilot study with the Cronbach alpha value of 0.78 . Quantitative data were analyzed through descriptive and inferential statistical techniques.

Findings: Results of this study indicated that there was a shortage of separate allocated ECE rooms, trained ECE teachers, Care-giver, ECE kits, learning corners, teacher-made toys, portfolios, and furnished playgrounds. The results of this study further revealed that on average the enrollment and retention rate of katchi in the year 2018 is higher than the enrollment and retention rate in katchi of the year 2013.

Implications/Originality/Value: This study was a comprehensive report about the ECE program in Punjab which will be very useful and informative for policymakers, administration of the Quaid-Azam academy for education development, Punjab to modify the program according to the need for achieving goals as well as researchers.

(C) 2021 The authors, under a Creative Commons AttributionNonCommercial 4.0

Recommended citation: Malik, S., and Asghar, Z. (2021). The Effectiveness of Early Childhood Education Program in Public Schools of Punjab. Journal of Business and Social Review in Emerging Economies, 7 (2), 329-341

\section{Introduction}

Early childhood Education (ECE) plays an important role in the whole child's development. It is 
considered a core phase in the holistic development of a child worldwide (Arshad \& Zamir, 2018; Bhutta, 2020; Saif, Inam \& Abiodullah, 2020). The world has committed to spreading it universally by the signatory to Education for All (EFA), Millennium Development Goal (MDGs), Sustainable Development Goals (SDGs), and Universal primary education (UPE) (UNESCO, 2019). Pakistan is making substantial efforts to spread ECE over its territory as a partner of these international commitments regarding ECE (MoE, 2017). ECE is provided in the form of preprimary education with the name of "Katchi class" for 3-5 years old children in public schools of Pakistan. Pakistan focused on ECE by implementing Article 25-A of the $18^{\text {th }}$ Amendment in April 2010 along with National Education Policy (NEP) 2009; NEP, 2017. Before the implementation of the Single National Curriculum, (2021) national ECE curriculum was designed in the year 2002 and revised in the year 2007 (AEPAM, 2017).

The "Punjab" (a province of Pakistan) is also accumulating extensive steps in spreading ECE over its territory as being the partner of all national commitments. Punjab has become the first province of Pakistan by launching the Early childhood Education Policy (ECEP), (2017) to achieve the settled targets of ECE. Quaid-e-Azam Academy for Educational Development (QAED), schools education department, Government of Punjab, was handed over the responsibility of launching ECE in public schools of Punjab by the government of Punjab in the year 2013 (GoP, 2017). QAED has launched the ECE program with the title "Introduction of ECE in Primary Schools in Punjab with High Enrollment and Improvement of Environment of Schools to convert them into Child-Friendly Schools (CFSs)" in its all 09 divisions and 36 districts since 2013 (QAED, 2018).

However, the anticipated benchmarks for the ultimate goal of $100 \%$ enrolment in ECE are consistently underachieved in Punjab. An extensive dropout ratio and a low rate of retention of students at the primary level in public schools are the major problems in Punjab (Bhutta, 2020). The prevailing ECE program could not be proved a source of solution to these problems. There is an enormous gap between policy and implementation in Punjab. Parents are more willing to register their children in private schools due to enormous differences in the provision of facilities between public and private schools (Arshad \& Zamir, 2018; Saif, Inam \& Abiodullah, 2020).

The increasing demand for early childhood education and less enrollment in public schools has placed question marks upon the given quality in public schools (Ismail \& Awan, 2019). Thus, it is the need of the hour to investigate and evaluate the prevailing program in public schools to benchmark the practices. So that the existed differences and deficiencies among the public schools may be explored. Therefore, the present research was intended to investigate the effectiveness of the Early Childhood Education Program in Public Schools of Punjab regarding the physical facilities as well as to find out retention rate and increase in enrollment at the primary level.

Objectives:

The objectives of the study were to:

- Examine the physical facilities of the Early Childhood Education program in public schools of Punjab.

- Compare the enrollment ratios and retention of ECE students.

\section{Research Questions}

1. How much is the availability of physical infrastructure for ECE in Public schools of Punjab?

2. What are the benefits of ECE program in terms of increasing the retention rate and enrollment? 


\section{Review of the Related Literature}

According to the global report of UNICEF, (2017) "Early moments matter for every child, showing the critical importance of the first years of a child's life. A child's brain is 90 percent developed by his fifth birthday, meaning that the foundations for success at school and in later life are already in place". Empirical research has proved that quality early childhood education proved as a change agent to change the adverse outcomes of poverty and it sets a positive cycle of long-life learning (Bailey, Duncan \& Odgers, 2017; Boat, Dinnebeil \& Bae, 2010; Jenkins \& Duncen, 2017; Luby et al., 2013; NAEYC, 2015; Thornton, 2019; UNICEF, 2019). By recognizing the importance of ECE, all the countries of the world have done so many international legislations for the dispersion of ECE e.g. Education for All (EFA), Universal Primary Education (UPE), Millennium Developmental Goals (MDGs), and Sustainable Developmental Goals(SDGs 4). SDG4 is applauded globally, "which ensures inclusive and equitable quality education and promotes lifelong learning opportunities for all. The adoption of SDG 4 offers a compelling opportunity to amplify global support and meet the promise of universal pre-primary education" (UNICEF, 2019). SDG-4 targets about ECE are:

4.1: By 2030, ensure that all girls and boys complete free, equitable, and quality primary and secondary education leading to relevant and Goal-4 effective learning outcomes.

4.2: By 2030, ensure that all girls and boys have access to quality early childhood development, care, and pre-primary education so that they are ready for primary education (UNESCO, 2015).

The need of delivering a quality ECE program is advocated by "OECD, World Bank, and UNICEF" based on cost/benefit analyses. The reports of these organizations have ascertained that the quality ECE provides higher rates of human capital return compared to investment at any other stage of life (Allen, 2009; Dahlberg, Moss \& Pence, 2007; Hunkin, 2018; UNICEF, 2019).

"Quality pre-primary programs can reduce the achievement gaps caused by poverty and help the most vulnerable children keep up with their peers" (UNICEF, 2019). National Association for the Education of Young Children (NAEYC) stipulates that "high-quality education can promote intellectual, language, physical, social, and emotional development, creating school readiness and building a foundation for later academic and social competence" (NAEYC, 2006; NAEYC, 2018). Development of skills (language, math, and social) at an early age can significantly influence the quality of care and education provided to children in ECE programs (Thornton, 2019). The high-quality ECE is a source of the development of critical thinking, collaboration, resilience, and creativity as the modern job market demands (UNICEF, 2019). Pianta, (2011) indicated that the effectiveness and quality of ECE could be enhanced by improving the capacity of ECE educators to enable them to understand the importance of learning through play and activity. NAEYC, (2018) released a list of 10 standards equated to quality early childhood programs, i.e., "Programs are required to meet standards grouped into ten areas: relationships with children, curriculum, teaching approaches, child assessment, nutrition and health, staff qualifications, relationship with children's families, relationship with the community, physical environment, and program leadership and management" (NAEYC, 2018, p. 1).

In the context of Pakistan, Islamic or Quranic education of a child is started at the age of 3 years old in form of three modes: formal, informal, and non-formal. This education is considered compulsory even in the remotest areas and mothers are very concerned to educate their children at an early age (Khan, 2018). It is estimated that $80 \%$ of children get an Islamic education between the ages of 3-5 years (Khan et al., 2017). There was the absence of public policies, investments, and commitments regarding ECE till the 1990s in Pakistan. After the commitment with the world Education Conference 1990 "EFA," ECE became prominent in the eyes of the Government as well as policymakers. Previously, ECE was delivered by a few private elite 
schools which fee was unaffordable for an ordinal person (Ahmed, 2011; Khan et al., 2017; Khan, 2018; Syeda, 2016; UNESCO, 2015).

A series of national education policies have been presented since 1947 in Pakistan (Ahsan, 2003; Bhutta, 2020). Which attributed the importance of ECE and access, quality and governance in the education sector of Pakistan i.e. National Education Conference (1947), Report of the Commission on National Education (1959), The Education Policy (1972), National Education Policy (1979), National Education Policy (1992), National Education Policy (1998), National Education Policy (2009), National Education Policy (2017).

Following are the key features of the National Education Policy (2017);

- Expand, strengthen, and promote universal, comprehensive Early Childhood Education to ensure the holistic development of children to prepare for formal schooling.

- Achieve universal quality primary education covering all the three dimensions/ aspects of universalization, i.e., universal access/enrolment, universal retention, and universal achievement by 2020 (MoE, 2017).

At present, there is an alarming situation regarding the performance of Pakistan on the rating scale of GER and NER, which is lagging to its neighboring countries i.e. Sri Lanka, Iran, Indonesia, Vietnam, Egypt, and India (ASER, 2019; UNESCO, 2015; World Bank, 2015).

On the other hand, when we talk about the accessibility of ECE, it is harsh to listen to that still to date, there is not physical accessibility to all children of the nation. People of rural areas as well as in urban areas are not sending their children ages 3-5 to the pre-primary school (AEPAM, 2018; Khan et al., 2017; Khan, 2018; Niamatullah et al., 2017; Shaheen \& Abida, 2012). Pakistan is still far away to achieve EFA, MDGs, and SDG4 goals because of having insufficient attention of policymakers as well as planning and managerial departments of the national and provincial levels due to lack of access, poor quality of education, equity, and governance. Other external factors include budgetary constraints and weak management (AEPAM, 2018; Khan et al., 2017; Syed, Asif \& Yousaf, 2011; Syeda, 2016; World Bank, 2015). Several types of research have analyzed the ECE program at the national level, and they are at the standpoint that ECE still needs much work to meet international commitments (Arshad \& Zamir, 2018; Bhutta, 2020; Hunzia \& Nisar, 2017; Ismail \& Awan, 2019; Khan et al., 2017; Khan, 2018; Niamatullah et al., 2017; Saif, Inam \& Abiodullah, 2020; Syeda, 2016). Policies are made by the statements that what to do but do not deal with who will do and when will do. To answer these questions, and to stop failure in policy, there shall be developed effective implementation framework feedback mechanism (Khan et al., 2017; MoE, 2017). In this current scenario of Early Childhood Education in Pakistan, there is a strong need of streamlining" ECE" for the sake of economy, proper utilization of workforce and benefitting the target group of the children possibly (Bhatti, 2017; Ismail \& Awan, 2019; Saif, Inam \& Abiodullah, 2020).

Positively, Punjab is the largest inhabited province of Pakistan, with 53 percent the highest enrolment rate in the pre-primary age group (ASER, 2015; Farooq, 2018; Ismail \& Awan, 2019). Besides it, ECE is not organized at the international level in Punjab by the administration. According to Arshad and Zamir (2018 ), Saif, Inam \& Abiodullah (2020), Shakeel and Aslam (2019), Naz, Yousaf, and Arshad, (2019) ECE in Punjab are not up to the satisfactory level despite implementing Punjab ECE policy 2017. The primary reason for failure is poor coordination between the School Education Department (SED) and government schools. Schools are lagging in achieving settled targets because of having scarce resources (Bhatti, 2007). According to Sabil, Feroze, and Tong (2017), getting higher ratios of enrollment in ECE is not only the way of achieving settled targets of UPE and other international commitments
Comment [MZA2]: Reference arrangement not APA

Comment [MZA3]: APA issue

Comment [MZA4]: APA 
nevertheless, but the need for the hour is also to retain student's ratios until the completion of primary education. Practically, Punjab has a $40 \%$ drop-out ratio at the primary level up till now despite launching the ECE program. The gap is to retain these dropout ratios (GoPb, 2017).

The annual report of Alif Ailaan, (2018) depicts the accomplishment of ECE in Punjab and affirms the implementation of ECE policy, 2017 along with the execution of ECE project by QAED. QAED has established over 5,000 ECE classrooms in government schools across the province. Due to launching the ECE program in Punjab, enormous increase in enrollment (almost over 300,000) has been reported in public schools with more than 5,000 trained teachers and a similar number of caregivers deployed in the ECE centers. QAED has provided ECE kits in the classrooms to facilitate the children. These steps have helped to bring the total enrolment in "kachi" to above 2.4 million children".

However, despite the initiatives as mentioned earlier, there are still few challenges that need to be addressed at the provisional level, i.e., Lack of school capacity, access and enrollment, low parental engagement, service delivery ( teacher recruitment policy) including institutional challenges which include implementation strategy by the head teachers and financial commitment to ECE (ASER, 2019). Out-of-school children (OSC) is another massive bump into the province "Punjab". PEMIS, 2019 reported 8.27 million children between 5 and 16 years old out of school in the 2013-14 in Punjab. So, there is a strong need to intensify provincial efforts in the provision of physical facilities along with the increasing enrolment capacity and retention of students beyond primary school age (ASER, 2019; I-SAPS, 2016; PMIU, 2019).

\section{Methodology}

A survey design was deployed for the identification of physical facilities of ECE in public schools of districts Punjab, i.e. Lahore, Okara, Toba Tek Singh, Gujranwala, Hafizabad, Faisalabad, Pakpatn, Kasur, Shakupura, Nankanasahib, Mainawali. Data was collected from 11 districts out of 14 districts of central Punjab through a random sampling technique. A convenient sampling technique was deployed in the selection of schools in the pandemic COVID-19. This study applied a self-made checklist, which was established with the consultation of interventions provided by QAED to measure the physical facilities of ECE in public schools. The reliability of the self-developed checklist was measured through the pilot study conducted in three districts i.e. Lahore, Okara, and Toba Tek Singh. The checklist comprises a list of facilities-based on two categories, i.e., physical facilities and instructional facilities. Physical facilities include boundary walls, toilets, three ECE rooms, ventilated rooms, three ECE teachers, presence of care-giver, clean water, presence of First aid box, chair per child, blackboard, ECE kit, portfolio, decorated ECE classroom (as per QAED instructions), play area, play equipment while instructional facilities deal with the indoor play equipment, display of children's artwork, presence of Audiovisual aids (AV aids) and accessibility of AV aids to children. Five experts from the relevant field measured the validity of the checklist. The Cronbach Alpha value for the reliability of the checklist was found 0.78 through "Statistical Package for Social Sciences" (SPSS) version 22.

\section{Findings}

Collected data were tabulated and analyzed by using different statistical techniques with the application of SPSS version 22.

Table 1: Descriptions of Districts

\begin{tabular}{lll}
\hline & F & Cumulative Percent \\
\hline Lahore & 100 & 16.4 \\
Okara & 128 & 37.4 \\
Toba Tak Singh & 100 & 53.8 \\
\hline
\end{tabular}




\begin{tabular}{lll}
\hline Gujranwala & 21 & 57.2 \\
Hafizabad & 21 & 60.7 \\
Faisalabad & 29 & 65.4 \\
Pakpatn & 26 & 69.7 \\
Kasur & 9 & 71.1 \\
Shakupura & 16 & 73.8 \\
Nankanasahib & 50 & 82.0 \\
Mainawali & 110 & 100.0 \\
Total & 610 & \\
\hline
\end{tabular}

Table 1 shows the percentage of collected data from the different districts of Punjab. $16.4 \%$ of data was collected from the district of Lahore. Meanwhile, data was collected from Okara, Toba Tak Singh, Gujranwala. Hafizaabad, Faisalabad , Pakpatn, Kasur, Shakupura, Nankanashaib and Mianawali: $21 \%, 16.4 \%, 3.4 \%, 3.4 \%, 4.8 \%, 4.3 \%, 1.5 \%, 2.6 \%, 8.2 \%$ and $18 \%$ respectively.

Table 2: Provision of Physical Facilities of ECE in Districts

\begin{tabular}{|c|c|c|c|}
\hline & & $\mathrm{N}$ & $\%$ \\
\hline \multirow[t]{2}{*}{ Boundary Wall } & yes & 602 & 98.2 \\
\hline & No & 8 & 1.1 \\
\hline \multirow[t]{2}{*}{ Toilets } & yes & 602 & 98.2 \\
\hline & No & 8 & 1.3 \\
\hline \multirow{2}{*}{ Clean Water } & yes & 608 & 99.2 \\
\hline & No & 2 & .3 \\
\hline \multirow[t]{2}{*}{3 ECE Rooms } & yes & 370 & 60.4 \\
\hline & No & 240 & 39.2 \\
\hline \multirow[t]{2}{*}{3 trained ECE Teachers } & yes & 43 & 7.0 \\
\hline & No & 567 & 92.5 \\
\hline \multirow[t]{2}{*}{ Lighting } & yes & 557 & 90.9 \\
\hline & No & 53 & 8.6 \\
\hline \multirow[t]{2}{*}{ Ventilation } & yes & 494 & 80.6 \\
\hline & No & 116 & 18.9 \\
\hline \multirow[t]{2}{*}{ Painting walls } & yes & 221 & 36.1 \\
\hline & No & 389 & 63.5 \\
\hline \multirow[t]{2}{*}{ Caregiver } & yes & 84 & 13.7 \\
\hline & No & 526 & 85.8 \\
\hline \multirow[t]{2}{*}{ First Aid Box } & yes & 413 & 67.4 \\
\hline & No & 197 & 32.1 \\
\hline \multirow[t]{2}{*}{ Chair per child } & yes & 491 & 80.1 \\
\hline & No & 119 & 19.4 \\
\hline \multirow[t]{2}{*}{ Black board } & yes & 582 & 94.9 \\
\hline & No & 28 & 4.6 \\
\hline \multirow[t]{2}{*}{ ECE KIT } & yes & 342 & 55.8 \\
\hline & No & 268 & 43.7 \\
\hline \multirow[t]{2}{*}{ Portfolio } & yes & 41 & 6.7 \\
\hline & No & 569 & 92.8 \\
\hline \multirow[t]{2}{*}{ Room décor } & yes & 368 & 60.0 \\
\hline & No & 242 & 39.5 \\
\hline \multirow[t]{2}{*}{ Language corner } & yes & 20 & 3.9 \\
\hline & No & 590 & 96.1 \\
\hline \multirow[t]{2}{*}{ Math corner } & yes & 16 & 2.6 \\
\hline & No & 594 & 96.9 \\
\hline \multirow[t]{2}{*}{ Reading corner } & yes & 47 & 7.7 \\
\hline & No & 563 & 91.8 \\
\hline \multirow[t]{2}{*}{ Art corner } & yes & 38 & 6.2 \\
\hline & No & 572 & 93.3 \\
\hline \multirow[t]{2}{*}{ Science corner } & yes & 37 & 5.9 \\
\hline & No & 573 & 94.1 \\
\hline \multirow[t]{2}{*}{ Outdoor play area } & yes & 500 & 81.6 \\
\hline & No & 110 & 17.9 \\
\hline \multirow[t]{2}{*}{ Play equipment } & Yes & 170 & 27.8 \\
\hline & No & 440 & 72.2 \\
\hline
\end{tabular}


Table 2 shows the provision of physical facilities of ECE in public schools of Punjab. It shows that there was a presence of boundary walls in $98.7 \%$ of public schools. While $1.1 \%$ of schools did not have boundary walls. $98.7 \%$ of schools had the facility of toilets for the children of ECE class. While $1.3 \%$ of schools were deprived of this facility for young kids. $99.7 \%$ of schools had this facility and $.3 \%$ of schools did not have clean water. $60.7 \%$ of schools had separate rooms allocated for the sections of ECE class. While 39.3\% of schools did not have three separate rooms as per the settled requirement of starting ECE class by QAED. $7 \%$ of schools had three trained ECE teachers by QAED. While $93 \%$ of schools did not have three trained ECE teachers. 91.3\% of ECE classrooms had adequate lighting. While $8.7 \%$ of ECE classrooms were missing this facility.

There were $81 \%$ ECE classroom which had appropriate ventilation system. Although, $19 \%$ of ECE classrooms were lagging to this facility. Only $36.2 \%$ of classrooms were meeting the settled criteria of the presence of decorated and colorful ECE classrooms as per QAED requirement and 63.8 had not colorful ECE classrooms. 13.8\% of ECE schools had hired caregivers privately. While $86.2 \%$ of schools did not hire a caregiver for the help of ECE teachers. The provision of the first-aid box for any emergency to ECE kids in ECE classroom was found in $67.7 \%$ schools which had it in the office of the headteacher, not in ECE classroom. While $32.3 \%$ did not have it not only in the ECE classroom but in the head teacher's office too. 80.5\% of ECE classrooms had the presence of chairs per child in the class of ECE. On the other hand, $19.5 \%$ of ECE classrooms were missing this facility for kids. 95.4\% ECE classroom had the availability of board in the ECE classrooms. 56.1\% of ECE schools had received the ECE kit provided by QAED. While $43.9 \%$ of schools had not provisioned ECE kits.

Prepared portfolios of children by ECE teachers were present in $6.7 \%$ of classrooms only. On the other hand, $93.3 \%$ of ECE class teachers had not prepared it. $60.3 \%$ of schools had colorfully decorated ECE classrooms as per QAED's instructions. While 39.7\% of schools had a traditional set up of ECE classrooms. 3.1\% of ECE classrooms had language corners as per QAED's instruction in the classroom. Although $96.7 \%$ of classrooms had not followed it.

There were only $2.6 \%$ of ECE classrooms that had maintained Math's corner in the classroom. Although $97.4 \%$ of classrooms had missed it. Only $7.7 \%$ of ECE classrooms had established a reading corner within the ECE classroom. While $92.3 \%$ of ECE classrooms had not established it. There were only 6.2\% ECE schools which had art corner within the ECE class. While 93.8\% of schools had not this provision in the premises of the ECE classrooms.

There were only 5.9\% ECE classrooms with managing science corner as per QAED instructions while $93.9 \%$ schools had lagging to this provision. $82 \%$ of schools had the presence of ample space for play outside the ECE classroom. On the other hand, $18 \%$ of schools had not enough space for outdoor play activities. The provision of play equipment in the playground for ECE children was present in the $27.8 \%$ of schools that had some sort of swings fixed in playgrounds but $72.8 \%$ of schools had not any type of swings in the playground for ECE children.

Table 3: Condition of learning facilities in ECE Classroom

\begin{tabular}{|c|c|c|c|}
\hline & & $\mathrm{F}$ & Cumulative Percent \\
\hline \multirow[t]{3}{*}{ Play Material } & VB & 95 & 15.6 \\
\hline & B & 204 & 49.0 \\
\hline & $\mathrm{G}$ & 191 & 80.3 \\
\hline
\end{tabular}




\begin{tabular}{|c|c|c|c|}
\hline & VG & 63 & 90.7 \\
\hline & EX & 57 & 100.0 \\
\hline \multirow[t]{5}{*}{ Display of Children's work } & VB & 82 & 13.4 \\
\hline & B & 189 & 44.4 \\
\hline & G & 206 & 78.2 \\
\hline & VG & 83 & 91.8 \\
\hline & EX & 50 & 100.0 \\
\hline \multirow{5}{*}{$\begin{array}{l}\text { Preparation of toys by ECE } \\
\text { Teacher }\end{array}$} & VB & 102 & 16.7 \\
\hline & B & 194 & 48.5 \\
\hline & G & 192 & 80.0 \\
\hline & VG & 84 & 93.8 \\
\hline & EX & 38 & 100.0 \\
\hline \multirow{6}{*}{$\begin{array}{l}\text { Presence of learning aids in } \\
\text { ECE Classroom }\end{array}$} & VB & 89 & 14.6 \\
\hline & B & 172 & 42.8 \\
\hline & $\mathrm{G}$ & 258 & 85.1 \\
\hline & VG & 55 & 94.1 \\
\hline & EX & 36 & 100.0 \\
\hline & Total & 610 & \\
\hline
\end{tabular}

Note: $\mathrm{VB}=$ very bad, $\mathrm{B}=$ bad, $\mathrm{G}=$ good, $\mathrm{VG}=$ very good, $\mathrm{EX}=$ excellent

Table 3 shows the condition of learning facilities of ECE in the schools. There were 33.4\% ECE classrooms that had bad condition of play material and $31.3 \%$ classrooms had a good condition of these play equipment. Whereas, $31 \%$ of schools have badly displayed the condition of artwork while $33.8 \%$ of ECE classrooms had good display conditions of artwork done by the ECE kids. The presence of quality prepared toys by teachers in the ECE classrooms show that $31.8 \%$ of ECE classrooms were badly equipped with teacher-made toys while $31.5 \%$ of ECE classrooms had a good type of teacher-made toys. Meanwhile, there were $28.2 \%$ of ECE classrooms badly equipped with learning aids. Although $42.3 \%$ of ECE classrooms had a good condition of learning aids. 
Table 4: Paired t-test of Enrollment

\begin{tabular}{|c|c|c|c|c|c|c|c|c|c|}
\hline & Paired Differences & Mean & $\begin{array}{l}\text { Std. } \\
\text { Deviation }\end{array}$ & $\begin{array}{l}\text { Std. Error } \\
\text { Mean }\end{array}$ & $\begin{array}{l}95 \% \\
\text { Interval } \\
\text { Difference } \\
\text { Lower }\end{array}$ & $\begin{array}{c}\text { Confidence } \\
\text { of the } \\
\text { Upper }\end{array}$ & $\mathrm{t}$ & $\mathrm{df}$ & $\mathrm{r}$ \\
\hline Pair 1 & katchi13 - katchi18 & -15.22 & 19.26 & 1.23 & -17.66 & -12.78 & -12.294 & 241 & $.66^{* *}$ \\
\hline Pair 2 & one 13 - one 18 & -14.81 & 16.13 & 1.03 & -16.85 & -12.76 & -14.283 & 241 & $.81^{* *}$ \\
\hline
\end{tabular}

Results of the paired-sample t-test in table 4 show that on the average the enrollment of katchi in the year 2018 is higher than enrollment in Katchi of the year 2013 (M [katchi13-katchi18] = 15.22, SD [katchi13-katchi18]= 19.26) at the .05 level of significance $(\mathrm{t}=-12.294, \mathrm{df}=241$, $\mathrm{p}<.05, \mathrm{r}=.53)$. On the average the enrollment in class one of the year 2018 is higer than the enrollment in class one in the year of 2013 ( $\mathrm{M}$ [one13-one18]= -14.81, SD [one13-one18]=16.13) at the .05 level of significance $(\mathrm{t}=-14.283, \mathrm{df}=241, \mathrm{p}<.05, \mathrm{r}=.81)$.

\begin{tabular}{llllll}
\multicolumn{7}{c}{ Table 5: Descriptive analysis of Paired Samples Statistics } \\
\hline \multirow{2}{*}{ Pair 1 } & Mean & N & SD & Std. Error Mean \\
& katchi13 & 31.56 & 242.00 & 23.1 & 1.49 \\
Pair 2 & katchi18 & 46.79 & 242.00 & 23.4 & 1.51 \\
& one13 & 32.90 & 242.00 & 24.3 & 1.57 \\
& one18 & 47.71 & 242.00 & 27.1 & 1.74
\end{tabular}

Note: katchi 13, katchi 18= enrollment of katchi class in 2013 and 2018

One13, one 18= enrollment of class one in 2013 and 2018

The descriptive analysis shows that enrollment of katchi class in the year of $2018(\mathrm{M}=46.79, \mathrm{SD}=$ 23.45) was higher as compared with the year of $2013(\mathrm{M}=31.56, \mathrm{SD}=23.12)$ While retention rate in class one in the year of $2018(\mathrm{M}=47.71, \mathrm{SD}=27.10) 2103$ was higher as compared with the year of $2013(\mathrm{M}=32.90, \mathrm{SD}=24.37)$ as shown in table 5 .

\section{Discussion and Conclusion}

The perspectives regarding early childhood programs have shifted from just care and supervision of children towards laying an educational foundation for young children for their academic and professional futures (Allgood, 2020). Various researches were conducted to explore the facilities of ECE in Punjab i.e. "(Arshad and Zamir, 2018; Bhatti, 2007; Bhutta, 2020; Shakeel and Aslam, 2019, Naz, Yousaf, and Arshad, 2019). The study conducted by Saif, inam and Abiodullah, (2020) explored the current status of katchi class concerning early childhood education policies and practices in Punjab. The findings stated that "primary schools providing katchi class show a poor and low quality of education which lacks basic infrastructure facilities, trained teachers and a holistic learning environment as instructed in the NCECE". Another study was conducted by Bhutta, (2020) to measure the availability of physical facilities at ECE classrooms in public schools which highlighted that provision of the classroom environment and physical facilities present at schools has a positive impact on school performance. The findings of his study highlighted the provision of ECE in public schools of Punjab which reported that there are currently missing factors of the quality classroom environment and physical facilities in public schools at a massive level.

The findings of this study highlighted that almost all schools have boundary walls, toilets, and clean water in public schools of Punjab. But the provision of three trained ECE teachers and allocation of three separate ECE rooms, fulfillment of the set criteria of the presence of decorated 
and colorful ECE classrooms as per QAED requirement, of hiring of caregiver to assist the ECE teachers, provision of the ECE kit provided by QAED, Prepared portfolios of children by ECE teachers, absence of different learning corners (language corner, math corner, reading corner, art corner, and science corner) within the classroom due to shortage of space in the ECE classrooms, provision of play equipment in the playground, good condition of play material in ECE classroom and well display of the children's artwork in the schools were not found in the majority of the schools. Furthermore, this study explored that on average the enrollment of katchi in the year 2018 is higher than enrollment in katchi of the year 2013, and on average the enrollment in class one of the year 2018 is higher than the enrollment in class one in the year of 2013. It is also revealed that the retention rate of katchi class in the year 2018 was higher as compared with the year 2013. While retention rate in class one in the year of 20182103 was higher as compared with the year of 2013.

\section{Recommendations}

Based on the findings of this study, the following suggestions were given:

1. The government should allocate separate budgets and resources for ECE in all public schools.

2. All public schools should be facilitated with trained ECE specialized teachers.

3. Trained caregivers to assist the ECE teachers should be hired permanently.

4. Self-developed Audio-Visual Aids at a cheap price should be prepared by the ECE teachers.

5. Display of children's artwork should be done properly to motivate the students.

6. Playgrounds should be equipped well with different types of swings.

\section{References}

Academy of Educational Planning and Management, (2017). Education and Professional Training Government of Pakistan. Ministry of Federal National Education Management Information System. Islamabad

Academy of Educational Planning and Management, (2018). Education and Professional Training Government of Pakistan. Ministry of Federal National Education Management Information System. Islamabad

Ahmad, M. (2011). Early childhood education in Pakistan: an international slogan waiting for national attention. Contemporary Issues in Early Childhood, 12(1), 86-93.

Ahsan, M. (2003). An analytical review of Pakistan's educational policies and plans. Research papers in education, 18(3), 259-280.

Alif Ailaan. (2018). 2013-2018 Five Years of Education Reforms in the Punjab. Wins, Losses and challenges for 2018-2023. Islamabad: Alif Ailaan. $50 \mathrm{pp}$.

Allen, C. R. (2009). Effect of early childhood education programs on school readiness. Lindenwood University.

Allgood, C. E. (2020). Fiscal Management Practices and Quality Programming in Early Childhood: The Impact of Administrator Preparation (Doctoral dissertation). Mississippi State University.

Arshad, M., \& Zamir, S. (2018). Situational Analysis of Early Childhood Education in Pakistan: Challenges and Solutions. Journal of Early Childhood Care and Education, 2(1), 135149.

Bailey, D., Duncan, G., \& Odgers, C. (2017). Preschool can provide a boost, but the gains can fade surprisingly fast. The Washington Post. Retrieved from https://www.washingtonpost.com/posteverything/wp/2017/02/17/preschool

Bhatti, L. R. (2007). Causes of Primary School Dropout from Tehsil Lahore and Shariqpur. (Unpublished Master Thesis). University of Punjab, Pakistan.

Bhutta, E. (2020). Early Childhood Education, Mediation Analysis; A measurement of Factors Affecting Performance of Public Schools of Punjab Pakistan. Pakistan Journal of 
Education, 36(3).

Boat, M., Dinnebeil, L., \& Bae, Y. (2010). Individualizing instruction in preschool classrooms.Dimensions of Early Childhood, 38, 4-10.

Dahlberg, G., Moss, P., \& Pence, A. (2007). Beyond quality in early childhood education and care: Languages of evaluation. Routledge.

Farooq, M. S. (2018). Millennium development goals (MDGs) and quality education situation in Pakistan at primary level. International Online Journal of Primary Education, 7(1), 1-23.

Government of Pakistan. (1999). Education for All: the year 2000 assessment. Pakistan Country Report. $\quad$ Retrieved

http://www2.unesco.org/wef/countryreports/pakistan/contents.html

Government of Pakistan (1959). Report of the Commission on National Education 1959. Islamabad: Ministry of Education.

Government of Pakistan (1979). National education policy and implementation programme. Islamabad: Ministry of Education.

Government of Pakistan (1998). Pakistan Population Census. Islamabad: Pakistan Census Organization. Retrieved from www.pbs.gov.pk/content/population-census

Government of Pakistan (2009). National Education Policy 2009.Islamabad: Ministry of Education. Retrieved from http://unesco.org.pk/education/teachereducation/files/National\%20Education\%20Policy.p $\underline{\mathrm{df}}$

Govt. of Punjab. (2010). Basic Foundation Module-11 (BFM-11.2010). Early childhood Plan. Lahore: DSD, Punjab.

Government of Pakistan (2017). National Education Policy 2017.Islamabad: Ministry of Education Government of Punjab (2017). Punjab Early Childhood Education Policy 2017. SED/PMIU-PESRP.

Hunkin, E. (2018). If not quality, then what? The discursive risks in early childhood quality reform. Discourse: Studies in the Cultural Politics of Education, 40(6), 917-929.

Hunzai \& Nisar. (2007). Early Years Education in Pakistan: Trends, Issues and Strategies. International Journal of Early Years Education, v15 n3 p297-309 Oct 2007.

Idara-e-Taleem-o-Aagahi. (2011). Annual Status of Education Report 2015. Retrieved from http://aserpakistan.org/document/aser/2015/reports/national/ASER_National_Report_20 $\underline{15 . p d f}$

Idara-e-Taleem-o-Aagahi. (2019). Annual Status of Education Report- ASER Pakistan 2019. Retrieved from http://aserpakistan.org/document/aser/2019/reports/national/ASER_National_2019.pdf

Ismail, M., \& Awan, A. G. (2019). Impact of Early Childhood Education on Students'Enrollment in Schools in District Multan-Pakistan. Global Journal of Management, Social Sciences and Humanities Vol 5 (4).

I-SAPS (2016). Public financing of education in Pakistan: Analysis of federal, provincial and district budgets 2010-2011 to 2016-2017. Islamabad: Institute of Social and Policy Sciences, 2016.

Jenkins, J. M, \& Duncan, G. J (2017). Do pre-kindergarten curricula matter. In J. V.MarcusJenkins \& G. Duncan, The current state of scientific knowledge on pre kindergarten effects (Ch. 4). Washington, DC: Brookings Institution \& Duke University. Retrieved from https://archive.org/stream/ERIC_ED574393/ERIC_ ED574393_djvu.txt

Khan, N., Bhatti, M, Aslam., Sabir, K.H.; and Shaista, S.B. (2017). Early Childhood Education in Pakistan. Islamabad: Academy of Educational Planning and Management Ministry of Federal Education and Professional Training.

Khan, M. A. (2018). The status of early childhood education in Pakistan: Inside stories. Contemporary Issues in Early Childhood, 19(3), 310-317. 
Luby, J., Belden, A., Botteron, K., Marrus, N., Harms, M. P., Babb, C., \& Barch, D. (2013). The effects of poverty on childhood brain development: The mediating effect of caregiving and stressful life events. JAMA Pediatrics, 167(12), 1135-1142. Retrieved from http://doi.org/10.1001/jamapediatrics.2013.3139

National Association for the Education of Young Children, (2006). NAEYC Standards for Early Childhood Professional Preparation. Retrieved from https://www.naeyc.org/sites/default/files/globally

National Association for the Education of Young Children. (2015). Developmentally appropriate practice and the common core state standards: framing the issues. Research brief. Washington, DC: NAEYC.

National Association for the Education of Young Children (2018). NAEYC Early Learning Program Accreditation Standards and Assessment Items. Retrieved from https://www.naeyc.org/sites/default/files/globally-shared/downloads/PDFs/accreditation/ early-learning/naeyc_early_learning_program_accreditation_standards_and_assessment _items_0.pdf

Naz, F., Yousaf, A., \& Arshad, N. (2019). Analysis of Early Childhood Education Practices in Public and Private Sector of Lahore. Journal of Early Childhood Care and Education, 3.

Niamatullah K, Nasir A, Muhammad BK, et al.(2017). Pakistan Education Statistics 2015-16. Retrieved from http://library.aepam.edu.pk/Books/Pakistan\%20Education\%20Statistics\%202015-16.pdf

Patton, M. (2011). Developmental evaluation: applying complexity concepts to enhance innovation and use. New York: Guilford Press.

Punjab Education Sector Plan 2019/20 - 2023/24. Government of Punjab. Retrieved from https://planipolis.iiep.unesco.org/sites/planipolis/files/ressources/pakistan-punjab-esp.pdf

QAED. (2019, August 3). BUILDING THE WEALTH OF NATIONS; Early Childhood Care Advance lifelong Learning. Retrieved from http://qaed.edu.pk/

Sabil Farooq, M., Feroze, N., \& Tong Kai, Y. (2017). Public Vs Private Quality Education at Primary Level In PAKISTAN. International Online Journal of Primary Education 6(2), 4-23.

Saif, J., Inam, A., \& Abiodullah, M. (2020). Status of katchi class in relation to early childhood education policies and practices in Punjab. Journal of Early Childhood Care and Education, 4, 165-182

Shakeel, N., \& Aslam, A. (2019). Challenges Primary School Teachers Face In The Implementation Of Early Childhood Education: Teachers Perception. Journal of Early Childhood Care and Education, 3.

Syed, S. Z., Asif, M., \& Yousaf, A. (2011). Rethinking ECE in Pakistan. Journal of Elementary Education, 21(2), 65-76.

Syeda, S. (2016). Early childhood professional development model of private schools in Punjab, Pakistan: A multiple case study (Doctoral dissertation), The University of NebraskaLincoln.

Thornton, K. (2019). Early Childhood Education Trainers' Knowledge and Use of Andragogical Principles (Published Doctoral dissertation). Walden University: UK.

UNESCO, (2015). Primary education for all children. Paris: UNESCO.

UNESCO, (2019). Migration, displacement and education: BUILDING BRIDGES, NOT WALLS:

UNESCO.

Retrieved

from https://en.unesco.org/sites/default/files/2019_gemr_migration_4_dec.pdf

UNICEF. (2019). A World Ready to Learn: Prioritizing quality early childhood education. New York.

United Nations Educational, Scientific and Cultural Organization, United Nations Children "s Fund. (2015). A human rights-based approach to education for all: A framework for the realization of children's rights to education and rights within education. Retrieved from 
http://www.unicef.org/publications/files/A_Human_Rights_Based_Approach_to_Education _for_All.pdf

The World Bank Annual Report, (2015). Financing the Post-2015 Sustainable Development Agenda. Retrieved from https://www.worldbank.org/en/about/annual-report-2015

Yousaf, G., Malik, S. (2007). Assessment of the quality of early childhood education in preschools of Lahore (unpublished Master thesis). Institute of Education and Research, Punjab University, Lahore. 